Canadian Journal of Fisheries and Aquatic Sciences

Canadian

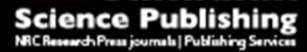

Journal canadien des sciences halieutiques et aquatiques

\title{
Principles Underlying the Epizootiology of Viral Hemorrhagic Septicemia in Pacific Herring and other Fishes throughout the North Pacific Ocean
}

\begin{tabular}{|r|l|}
\hline Journal: & Canadian Journal of Fisheries and Aquatic Sciences \\
\hline Manuscript ID & cjfas-2015-0417.R1 \\
\hline Manuscript Type: & Perspective \\
\hline Date Submitted by the Author: & 30 -Oct-2015 \\
\hline Complete List of Authors: & $\begin{array}{l}\text { Hershberger, Paul; U.S. Geological Survey, Marrowstone Marine Field } \\
\text { Station } \\
\text { Garver, Kyle; Fisheries and Oceans Canada, Pacific Biological Station } \\
\text { Winton, James; U.S. Geological Survey, Western Fisheries Research Center }\end{array}$ \\
\hline Keyword: & $\begin{array}{l}\text { DISEASES < General, MARINE FISHES < General, FISHES < Organisms, } \\
\text { VIRUSES < Organisms }\end{array}$ \\
\hline
\end{tabular}


1

2 Principles Underlying the Epizootiology of Viral Hemorrhagic Septicemia in Pacific Herring and 3

4

5

6

7

8

9

10

11

12

13

14

15

16

17

18

19

20

21

22

23 Keywords: VHS, viral hemorrhagic septicemia, herring, disease ecology other Fishes throughout the North Pacific Ocean

Paul K. Hershberger ${ }^{1}$, Kyle A. Garver ${ }^{2}$, James R. Winton ${ }^{3}$

${ }^{1}$ U. S. Geological Survey

Western Fisheries Research Center

Marrowstone Marine Field Station

Nordland, WA 98358, USA

phershberger@usgs.gov

Telephone: 360-385-1007, Ext 225 FAX: 360-385-7207

${ }^{2}$ Fisheries and Oceans, Canada

Pacific Biological Station

Nanaimo, BC V9T 6N7, Canada

Kyle.Garver@dfo-mpo.gc.ca

${ }^{3}$ U. S. Geological Survey

Western Fisheries Research Center

Seattle, WA 98115, USA

jwinton@usgs.gov

1

https://mc06.manuscriptcentral.com/cjfas-pubs 


\section{Abstract:}

25 Although viral hemorrhagic septicemia virus (VHSV) typically occurs at low prevalence and intensity in natural populations of Pacific herring (Clupea pallasii) and other marine fishes in the

27 NE Pacific Ocean, epizootics of the resulting disease (VHS) periodically occur, often in

28 association with observed fish kills. Here we identify a list of principles, based on a combination

29 of field studies, controlled laboratory experiments, and previously un-published observations, 30 that govern the epizootiology of VHS in Pacific herring. A thorough understanding of these

31 principles provides the basis for identifying risk factors that predispose certain marine fish

32 populations to VHS epizootics; including the lack of population resistance, presence of chronic

33 viral carriers in a population, copious viral shedding by infected individuals, cool water

34 temperatures, limited water circulation patterns, and gregarious host behavioral patterns.

35 Further, these principles are used to define the epizootiological stages of the disease in Pacific

36 herring, including the susceptible (where susceptible individuals predominate a school or sub-

37 population), enzootic (where infection prevalence and intensity are often below the limits of

38 reasonable laboratory detection), disease amplification (where infection prevalence and intensity

39 increase rapidly), outbreak (often accompanied by host mortalities with high virus loads and

40 active shedding), recovery (in which the mortality rate and virus load decline due to an active

41 host immune response) and refractory stages (characterized by little or no susceptibility and

42 where viral clearance occurs in most VHS survivors). In addition to providing a foundation for

43 quantitatively assessing the potential risks of future VHS epizootics in Pacific herring, these

44 principles provide insights into the epizootiology of VHS in other fish communities where 45 susceptible species exist. 


\section{Introduction}

As a dominant member of the forage fish assemblage in the North Pacific Ocean, Pacific herring (Clupea pallasii) provide a critical link in the flow of energy and nutrients from lower trophic levels to higher order predators. Forage fishes in many systems, particularly those driven by upwelling currents, are regarded as the major determinant of ecosystem productivity through a concept commonly referred to as the 'wasp waist hypothesis' (Fauchald et al. 2011). In contrast to bottom-up or top-down regulation of ecosystem function, the wasp waist hypothesis contends that constraints on ecosystem productivity are set at the forage fish level, rather than at the basal level of primary production or at the level of higher-order predators (Cury et al. 2000). As such, any perturbations to the size or species assemblages of forage fish communities are expected to resonate throughout both the upper and lower trophic levels. It is likely then, that functional change in ecosystem structure is mediated by oscillations in forage fish species abundance. Causes of these naturally-driven population fluctuations remain particularly difficult to study; however, mortality from infectious and parasitic diseases is believed to be an important factor in some forage fish populations (Marty et al. 1998, 2003, 2010).

Once thought to be solely a problem of the European rainbow trout industry, viral

62 hemorrhagic septicemia virus (VHSV) is now known to occur in freshwater and marine fishes throughout the northern hemisphere (Kim \& Faisal 2011), with different genotypes and subtypes occurring throughout this range (Snow et al. 2004). Genotype IVa has a broad natural host range in marine fishes throughout the North Pacific Ocean, including wild and cultured species in North America and Asia, where it is responsible for periodic disease epizootics (Isshiki et al.

67 2001; Hedrick 2003; Garver et al. 2013). Throughout this range, Pacific herring and other forage fishes are extremely susceptible to the resulting disease; as such, they play a critical role in its 
epizootiology. This observation creates an apparent paradox in our understanding of the disease, whereby the highly-virulent virus persists for extended periods in populations of a highlysusceptible host, yet disease epizootics occur only infrequently (Figure 1). The intent of this manuscript is to identify the principles controlling the epizootiology of VHS in the North Pacific by combining the results of previously-published field investigations and controlled laboratory studies (primarily involving Pacific herring) with previously unpublished observations of VHS in Pacific herring. These principles are then used to describe the epizootiological stages of the disease, including the enzootic periods and the irreversible cascade of events that culminate in epizootics. Throughout the manuscript, we focus our attention primarily on Pacific herring because the vast majority of cause-and-effect relationships in marine fish populations of the NE Pacific have been established with this host species. However, the principles and concepts discussed here are broadly applicable to Pacific sardines (Sardinops sagax; Arkoosh et al. 2006), Pacific sandlance (Ammodytes hexapterus; Kocan et al. 2001a), and other susceptible forage fishes in the NE Pacific (Hedrick et al. 2003) and other VHSV enzootic areas (Altuntas et al. 2010).

\section{Principle \#1: Pacific herring are exceptionally susceptible to VHSV}

In the North Pacific, Pacific herring are often infected with multiple pathogens, including VHSV, Ichthyophonus hoferi, erythrocytic necrosis virus (ENV), liver and intestinal coccidians, nematodes, cestodes, and sea lice. (Marty et al. 1998). While most are generally considered secondary pathogens of negligible importance as a proximate mortality factors, others (including VHSV, Ichthyophonus sp. and ENV) are primary pathogens of Pacific herring and can cause direct host mortality (Kocan et al. 1997, 1999; Hershberger et al. 2009). Recurring epizootics of VHS have caused fish kills in Pacific herring and other forage fishes (Garver et al. 2013). These 
92 observations are supported by numerous controlled laboratory studies which indicate that naïve

93 Pacific herring are highly susceptible to VHS (Kocan et al. 1997; Hershberger et al. 2007, 2010).

94 Pacific herring, therefore, may be considered an exceptionally susceptible host species, with

95 waterborne exposure levels as low as $10^{1}$ virus particles (plaque-forming units, $\mathrm{PFU}$ ) $/ \mathrm{mL}$

96 capable of initiating epizootics in laboratory exposures (Hershberger et al. 2011a). Additionally,

97 the virus is capable of infecting and killing previously-naïve Pacific herring when injected into

98 the body cavity at a calculated dose of $0.07 \mathrm{PFU} /$ fish, a level below the detection threshold of a

99 standard viral plaque assay (Hershberger et al. 2011a).

100

101

102

103

104

105

106

107

108

109

110

111

112

113

\section{Principle \#2: Pacific herring are super-shedders of VHSV}

After exposure to the virus and successful establishment of infection, Pacific herring and other species shed copious amounts of VHSV into the water (Kocan et al. 1997; Hershberger et al. 2010a; Kim \& Faisal 2012). Shed VHSV can be detected in the water as early as 4-5d postexposure, prior to the onset of host mortality from the resulting disease. Viral shedding peaks 6$10 \mathrm{~d}$ post-exposure and high levels of shed virus are no longer detectable after 16d. During the shedding peak, each diseased host sheds an average of 500 million PFU into the water each day (Hershberger et al. 2010a). The progression of viral shedding is extremely temperaturedependent, with lower temperatures generally resulting in higher shedding levels and delayed peaks in viral shedding (Hershberger et al 2013). It is likely that low-level viral shedding continues beyond $16 \mathrm{~d}$, after which infectious waterborne virions are generally no longer detectable using standard virus isolation procedures. In the wild, an abundance of super-shedders in a population likely results in the rapid amplification of exogenous virus, thereby providing a critical early step in the irreversible cascade of events that culminate in a VHS outbreak. 
114

\section{Principle \#3: Pacific herring serve as reservoirs of VHSV}

Impediments to our understanding of the ecology of VHSV in the Pacific Ocean previously resulted from negative surveillance data, inadequate sampling efforts that have been directed mostly towards species of high economic value, and incorrect assumptions regarding the potential reservoirs of VHSV in the marine environment. Surveys of wild marine fishes intended to identify reservoir hosts typically returned very low VHSV infection prevalence (Kent et al. 1998; Mortenson et al. 1999; King et al. 2001; Dixon et al. 2003; Gadd et al. 2011; Matejusova et al. 2010), except for the intermittent detection of VHSV at low prevalence and intensity in Pacific herring (Kent et al. 1998) and returning adult Pacific salmonids (Winton et al. 1991). However, the low species susceptibility of Pacific salmonids indicated that they represented an inadvertent host (Follett et al. 1997) and not a reliable reservoir capable of maintaining VHSV between epizootics. Pacific herring and other highly susceptible species were initially excluded as important reservoir hosts because standard 60-fish tissue samples frequently failed to test positive. Further, when laboratory studies indicated the extreme susceptibility and high mortality of Pacific herring following exposure to VHS virus, these data appeared to be incongruous with the classic perception of a reservoir host having a relatively low susceptibility to the disease.

However, the involvement of Pacific herring and likely other highly susceptible fishes including Pacific sardines, walleye pollock (Theragra chalcogramma), and Pacific sandlances in the perpetuation of VHSV in the NE Pacific was recently recognized by combining lines of evidence from field observations, manipulations of wild herring, and controlled laboratory studies. Although surveys of wild herring utilizing sensitive VHSV diagnostics typically fail to return VHSV-positive tissue samples, the confinement of wild herring into net pens or laboratory tanks often results in rapid escalation of VHS epizootics that involve nearly all the confined 
137 individuals (Kocan et al. 2001). This observation indicated that VHSV is maintained covertly in 138 populations of wild Pacific herring at an extremely low prevalence that is often undetectable 139 even by the highly sensitive cell culture and quantitative PCR techniques (Garver et al. 2011) on $140>60$ fish samples; however, the virus can quickly express in the same population in response to 141 stressful physical conditions including capture, handling, transport, and/or confinement of these 142 individuals. The mechanism(s) of viral persistence in these populations likely involves some 143 combination of chronic infections among neurotropic carriers (Lovy et al. 2012), active 144 infections with viral shedding by a very small percentage of individuals (Hershberger et al. 145 2010a), and low-level replication of the virus in partially-immune individuals (Hershberger et al. 146 2010b).

\section{Principle \#4: Co-factors influence the potential for VHS epizootics}

Numerous host and environmental factors influence the potential for VHS outbreaks,

149 including ambient temperatures, weather / climatic conditions, diet, and conditions that impact

150 infection pressures including water exchange rates, gregarious host behaviors, and proximity to

151 VHSV reservoir species. The susceptibility of Pacific herring to VHS is inversely related to 152 ambient seawater temperature, as evidenced by higher cumulative mortalities, greater viral 153 shedding, and longer viral persistence in the tissues of survivors at cooler temperatures

154 (Hershberger et al. 2013). Once shed into the water, the stability of exogenous VHSV increases 155 with the amount of proteinaceous material in the water (especially fish spawning products;

156 Kocan et al. 2001b), decreasing salinity, decreasing ambient temperatures (Hawley \& Garver 157 2008), and decreased ultraviolet irradiation (Oye and Rimstad 2001). Although the effects of 158 natural diet items on host susceptibility remain uninvestigated, the provision of various 159 commercially-available pelleted feeds to captive herring results in host susceptibility differences 
160 (Beaulaurier et al. 2012). Tidal and wind-driven water circulation patterns can influence the titer 161 of waterborne VHS virus within fjords and embayments where limited water exchange may 162 occur; additionally, advection currents from an area with a localized epizootic may result in 163 expansion of localized epizootics to much broader areas as modeled for other aquatic viruses 164 (Foreman et al. 2015; Salama and Rabe 2013). Finally, certain predator-avoidance behaviors of 165 Pacific herring and other pelagic forages fishes, including the coalescence of schools and shoals 166 into extremely tight aggregations, are conducive to transmission of VHSV.

Principle \#5: Acquired Resistance is a critical determinant of VHS potential

Although immunologically naïve Pacific herring are highly susceptible to VHS, survivors of the disease develop, at optimal temperatures, a long-lived adaptive immunity that results in virus clearance and resistance to the disease. VHS progression in susceptible Pacific herring can

171 be extremely rapid, with detectable levels of virus occurring in the tissues of exposed herring as

172 early as $2 \mathrm{~d}$ post-exposure (P. E.), and mortality from the disease occurring as early as $4 \mathrm{~d}$ P. E.

173 (Kocan et al. 1997; Hershberger et al. 2010c). However, the pace, intensity, and outcome of the

174 disease are highly dependent on several variables including exposure level and duration, 175 temperature, diet, water exchange rate, and other factors (Hershberger et al. 2011a, 2013).

176 Regardless of the disease progression and magnitude, herring surviving an active case of VHS

177 develop solid resistance to future recurrences of the disease even after their subsequent exposure 178 to high levels of VHSV (Hershberger et al. 2010c). Therefore, the susceptibility of Pacific 179 herring to VHS (and the potential for VHS epizootics) typically decreases with the host age; not as a result of an increased innate immune response; rather because older cohorts are more likely

181 to have survived prior infection and developed acquired resistance. This acquired resistance 182 supersedes all other disease co-factors, and a resistant population will not experience a VHS 
183 epizootic even if all other disease co-factors (i.e. exposure to high levels of the virus, cool 184 temperatures, tight aggregations, etc.) are present. However, situations can occur where older age 185 cohorts remain naïve to the virus and retain their high level of susceptibility to the disease 186 (Garver et al. 2013); indeed, several VHS epizootics have been documented in wild adult herring 187 and lifelong susceptibility is seen in laboratory colonies of adult Pacific herring that were reared 188 under specific pathogen-free conditions.

\section{Stages of VHS Epizootics}

Taken together, these five principles provide insights into the developmental stages of

192 VHS epizootics. These epizootiological stages include the susceptible (where susceptible

193 individuals predominate a school or sub-population), enzootic (where infection prevalence and

194 intensity are often below the limits of reasonable laboratory detection), disease amplification

195 (where infection prevalence and intensity increase rapidly), outbreak (often accompanied by host 196 mortalities with high virus loads and active shedding), recovery (in which the mortality rate and 197 virus load decline due to a robust host immune response) and refractory stages (characterized by 198 little or no susceptibility and where viral clearance occurs in most VHS survivors). By 199 identifying the particular epizootiological stage of a population, insights can be gained into the 200 potential for future epizootics.

\section{Susceptible Stage}

As there is no evidence for vertical transfer of humoral immunity from parents to

203 progeny, all herring and other susceptible fishes are born into the VHS-susceptible stage.

204 Although newly-hatched herring larvae are susceptible to VHS (Hershberger et al. 2007), natural 
205 exposure to the virus does not likely occur until sometime after the 2-3 mo larval period, when

206 newly-metamorphosed juvenile cohorts begin to venture beyond the nearshore areas and become

207 sympatric with other reservoir fishes. As such, expansive geographic areas often experience a

208 large influx of susceptible cohorts near the end of July / beginning of August, as massive schools

209 of newly-metamorphosed Pacific herring juveniles begin sharing habit with potential VHSV

210 carriers in older age cohorts. This large annual influx of susceptibles can tip the overall balance

211 of population resistance within geographic locations, thereby increasing the potential for

212 epizootics.

As herring do not possess a high level of innate resistance to VHS, their susceptibility to

214 the disease persists until after they experience infection with the virus and subsequently develop

215 adaptive immunity. Therefore, the probability of herring converting from the susceptible stage

216 to the refractory stage increases with host age, as the probability of surviving prior infection with

217 the virus also increases with time. However, it should be emphasized that older herring age

218 cohorts can remain susceptible to the disease if they have never experienced prior exposure, as is

219 evidenced by documentation of periodic VHS epizootics involving adult herring throughout

220 coastal waters of British Columbia, Canada (Garver et al. 2013), and documented epizootics

221 among confined herring cohorts that were predominated by newly-recruited age 3-4 yr cohorts

222 (Hershberger et al. 1999).

223 Enzootic Stage

Under typical enzootic situations, an extremely low prevalence of VHSV infections often

225 persists-in and cycles-through susceptible schools of Pacific herring. As VHSV is not vertically

226 passed from parents to progeny (Wolf 1988), the first infections in each susceptible school likely 
227 occur as a result of exposure to shed virus from sympatric schools of Pacific herring, Pacific

228 sandlance, Pacific sardines, or other natural reservoirs. Once the school is exposed, the infection

229 prevalence often remains below the reasonable detection limits of standard field surveillance

230 techniques. However, the existence of VHS virus in these schools is verified by the detection of

231 shed VHS virus in the static water used to transport several thousand live individuals from these

232 pre-patent schools back to the laboratory (Kocan et al. 2001a). Further, rapid escalation of VHS

233 epizootics results after these individuals are confined into laboratory tanks, net pens, or other

234 areas with limited water exchange (Kocan et al. 2001a; Hershberger et al. 1999). The enzootic

235 prevalence of these virus-positive individuals likely changes throughout the year (Altunas \&

236 Ugut 2010), however, their presence in a population can be further confirmed by the non-random

237 selection of symptomatic individuals from a collection. For example, during beach seining

238 efforts in the San Juan Island regions of Puget Sound, WA during September, 2014, fisheries

239 biologists observed that some proportion of their seine hauls contained herring with ulcerative

240 lesions reminiscent of those associated with VHS. Samples of these symptomatic individuals

241 were high-graded from each of two sets, frozen at $-20^{\circ} \mathrm{C}$, and submitted for cell culture

242 approximately 1 month later. Even under these sub-optimal conditions for virus stability

243 (Arkush et al. 2006), VHS virus was recovered from 27\% (6/22) and 12.5\% (3/24) of the

244 selected samples, with tissue titers as high as $5 \times 10^{3} \mathrm{PFU} / \mathrm{g}$ (Hershberger unpublished data).

245 Although the true infection prevalence in the population remained unknown, these positive

246 surveillance data indicate that the virus was maintained in the herring schools at sub-epizootic

247 levels.

Long-term VHS virus persistence in this enzootic stage likely involves a combination of 
250 of VHS can develop a neurotropic stage of the disease that is characterized by the long-term

251 persistence of virions in the brain and peripheral nerves (Lovy et al. 2013). Although this

252 neurotropic stage provides a means of VHSV persistence within individual herring, it remains

253 unknown whether these neurotropic carriers are capable of transmitting the virus. Continuous

254 cycling of VHS virus within a herring aggregation occurs through a combination of viral

255 shedding from infected individuals and the super-susceptibility of sympatric, naïve herring.

256 Recovered individuals are also likely involved in this virus perpetuation strategy, as their re-

257 exposure to exogenous virus can result in infection and additional virus replication, even though

258 they are refractory to disease (Hershberger et al. 2010c). The long-term temperance of VHS

259 virus within this sub-patent stage requires a delicate balance between the exacerbating forces (i.e.

260 gregarious herring schooling behavior, low herd immunity, high $\mathrm{R}_{0}$ - the basic viral reproduction

261 number, etc.) and the alleviating forces of virus dilution that are influenced by herring vagility

262 and hydrological patterns in coastal areas.

263 Disease Amplification Stage

Disease amplification is defined as the irreversible transition from the enzootic stage to

265 the outbreak stage, characterized by elevated infection pressures or reduction in host resistance

266 that results from a change in pathogen, host, or environmental conditions.

Changes in the pathogen can be mediated by genetic mutations affecting virulence.

268 Because the RNA polymerases in VHSV and other RNA viruses lack proof-reading activity,

269 their replication error rates are much higher than those of DNA viruses (Holland et al. 1982).

270 For example, among 63 VHSV isolates recovered from coastal fishes around British Columbia,

271 Canada over a 19 year period, genetic sequencing of the glycoprotein gene (1524 nt region) 
272 revealed 42 sequence types with a maximum pairwise diversity of $2 \%$ (30 nt differences). The

273 majority (72\%) of the variants did not result in changes to the deduced amino acid sequence

274 relative to the consensus wild type (Garver et al. 2013) and the ecological significance of these

275 genetic variants remains poorly understood. Interestingly, multiple genetic variants have been

276 detected from herring in the same school and laboratory challenge studies indicate that a single

277 host species (Atlantic salmon) can demonstrate differences in susceptibility to these naturally-

278 occurring variants (Traxler, Garver and Hershberger unpublished data). Therefore, it is possible

279 that the onset of new epizootics may be initiated by the rapid emergence of new variants

280 demonstrating increased viral fitness.

281

282

283

284

285

286

287

288

289

290

291

292

293

294

Host behavioral responses can also facilitate the transition from pre-patency to disease amplification. For example, Pacific herring and several other species of forage fish are comprised of large schools and shoals that, when confronted by a predator, often converge into extremely tight aggregations in an effort to confuse and deter the attacker(s) Although effective for its intended purpose, an unintended consequence of this behavior involves an elevated transmission potential resulting from the proximity of susceptible individuals to virus-positive and -shedding individuals within the school. An analogous proximity mechanism resulting in elevated infection pressures occurs in some Pacific herring fisheries, where wild cohorts are captured and confined into marine net pens (Hershberger et al. 1999); the magnitude of the ensuing epizootics inside the pens has generated concerns of spill-back to free-ranging populations.

Human activities as well as annual changes in population structure can also facilitate a transition from pre-patency to active VHS amplification. For example, because the potential for prior exposure to VHS virus increases as a cohort of Pacific herring ages, the potential for 
295 population resistance also increases directly with the median age of the population. However,

296 because protective antibodies against VHS are not passed vertically from parents to their

297 progeny, the appearance of newly-metamorphosed juvenile herring constitutes a large influx of

298 susceptible individuals into the system each year. Pacific herring school often by age class;

299 nonetheless age structuring is dynamic, and schools containing multiple age classes are not

300 uncommon (Taylor and Kieser 1982). If, at the time of recruitment and integration into the

301 adult population (typically at the age of 2-4 years), younger age classes have not yet developed

302 acquired resistance, then the balance of population resistance can tip towards susceptibility.

303 Consequently, it is likely that the level of population resistance can be affected by human

304 activities such as commercial herring roe fisheries which selectively remove the oldest, most

305 refractory cohorts and leave the youngest, most susceptible individuals.

Another consequence of the annual influx of susceptible herring involves anthropogenic

307 activities associated with the culture of Atlantic salmon in marine net pens. Although Pacific

308 salmonids (Oncorhynchus spp.) generally demonstrate negligible susceptibility to VHS

309 (genogroup IVa), Atlantic salmon (Salmo salar) are a moderately susceptible species (Lovy et al.

3102013 ) and VHS epizootics periodically occur in farm operations throughout Washington and

311 British Columbia (Garver et al. 2013). Newly-metamorphosed juvenile herring often venture

312 through the mesh of Atlantic salmon net pens, and utilize the confines of the net pen as a shelter

313 from natural predators. With an abundant supply of exogenous food inside the pens, the herring

314 quickly attain a size that prevents their emmigration back through the mesh. This presents an

315 optimal situation for the formation of VHS epizootics inside the pens, as a highly-susceptible

316 species (Pacific herring) is maintained in close proximity to a moderately-susceptible species

317 (Atlantic salmon). As a result, concurrent isolations of VHS virus from both species are typical 
318 during documented epizootics in Atlantic salmon net pens (Garver et al. 2013). Further,

319 laboratory exposure studies have successfully demonstrated VHSV spill-over and spill-back

320 between Atlantic salmon and Pacific herring (Lovy et al. 2013).

Interannual changes in community structure can also affect infection pressures, thereby

322 facilitating the transition from pre-patency to active VHS amplification. For example, Pacific

323 sardines, a species that typically occupies warmer waters around California, periodically

324 establish residency in the more temperate coastal waters around Washington state and

325 Vancouver, Canada. When present, they often occur in extremely large numbers that are

326 sufficient to justify commercial harvest (MacFarlane \& Beamish 2001). As Pacific sardines also

327 represent a super-susceptible species (Arkush et al. 2006), VHS epizootics among free-ranging

328 fishes in British Columbia often involve mixed assemblages of both Pacific sardines and Pacific

329 herring (Hedrick et al. 2003; Garver et al. 2013). Although investigation of these events is

330 incapable of assigning directionality between the involved species, changes in community

331 assemblages can certainly lead to increased infection pressures, especially when the assemblage

332 is transiently predominated by a high percentage of naïve individuals of a susceptible species

333 such as Pacific herring, Pacific sardines, Pacific sandlance, and walleye pollock.

Changing environmental conditions can affect infection pressures by influencing host

335 susceptibility or characteristics of the pathogen. For example, the stability of waterborne VHSV

336 affects infection pressures by establishing the duration of infectivity for shed virions (Hawley \&

337 Garver 2008). Therefore a transition to the disease amplification stage is more likely to occur

338 during conditions that are conducive for virus stability, such as low water temperatures (Hawley

$339 \&$ Garver 2008), elevated protein content and/or spawning products in the water (Kocan et al.

340 2001b), and periods of low ultraviolet irradiation (Oye \& Rimstad 2001). Low water 
341 temperatures constitute a further risk factor for VHS epizootics because host susceptibility is

342 inversely related to temperature, with cooler temperatures resulting in greater cumulative

343 mortalities, viral shedding, and viral persistence in the tissues (Hershberger et al. 2013; Goodwin

344 \& Merry 2011). In fact, the VHS epizootics involving Pacific sardines and Pacific herring in

345 British Columbia typically occur at times or in locations with declining water temperatures

346 (Hedrick et al. 2003). This inverse relationship with temperature is likely mediated by an

347 enhanced host immune response at warmer temperatures where a robust type 1 interferon

348 response occurs (Hershberger et al. 2013). Additionally, disease potential increases when large

349 schools transiently venture into embayments or other geomorphic locations that experience

350 limited water exchange. Low levels of shed virus can accumulate quickly in these areas,

351 resulting in increased probability of fish exposure to exogenous VHSV.

352 Outbreak Stage

Once the disease amplification stage is initiated by host, pathogen, or environmental

354 changes, the resulting epizootic cascade is often irreversible and an active disease outbreak

355 typically ensues. Laboratory exposure studies indicate that acute mortalities occurring during the 356 early outbreak period often occur prior to the onset of external signs of disease. Unfortunately, 357 in populations of wild marine fishes, the majority of VHS outbreaks likely go unnoticed because

358 of observational difficulties inherent to coastal marine ecosystems, lack of routine disease

359 surveillance in wild marine fishes, and the occurrence of cryptic or smaller-scale VHS outbreaks

360 that may not necessarily be accompanied by mass mortalities. Although some VHS outbreaks in

361 marine fishes are periodically documented, especially those occurring in close proximity to

362 populated areas or mariculture facilities (Garver et al. 2013), most are likely to occur in areas

363 that escape human observation. Documentation of these cryptic epizootics is further hampered 
364 by a lack of fish health surveillance programs in wild marine fishes, an information gap that 365 remains outside the jurisdiction of state, provincial, federal, and international management 366 authorities. Although small-scale VHSV surveys have been implemented for some herring 367 populations in recent years, including Sitka Sound and Prince William Sound, AK, virus 368 isolations from traditional 60 fish samples are rare during the pre-epizootic phase of VHS virus 369 persistence. However, the early stages of a VHS epizootic were detected in a random sample of 370 juvenile Pacific herring (mean length = $108 \mathrm{~mm}$ ) from Sitka Sound in March 2011, when 63\%

$371(38 / 60)$ tested positive for VHSV (Hershberger unpublished data). Of the positive tissues, nearly 372 half had high viral titers $(>40,000 \mathrm{PFU} / \mathrm{g})$. No mortalities or signs of abnormal behavior were 373 observed at the time of sample collection. This aggregation of virus-positive herring was 374 geographically distinct from aggregations of adult pre-spawn herring in the region (mean length $375=232 \mathrm{~mm})$, which failed to test positive for VHSV $(\mathrm{n}=60)$. Recovery Stage appearance of survivors that demonstrate classic signs of hemorrhaging on internal organs, near 379 the fin bases, and around the eyes. Although VHS is typically described as an acute disease characterized by rapid disease progression and mortality, a chronic manifestation of the disease

381 can also occur - characterized by slower disease progression, lower mortalities, and a prolonged 382 recovery period (Hershberger et al. 2010b). The disease trajectory is likely determined by host 383 and environmental conditions that occur during the early stages of host infection. For example, a 384 chronic trajectory is likely to occur in a population with a significant fraction of immune 385 individuals or during warm water periods when a robust type 1 interferon response is effective at 386 outpacing early viral replication (Hershberger et al. 2013). This early innate response provides 
387 adequate protection until further adaptive responses are mounted. However, an acute trajectory,

388 characterized by a preponderance of mortalities, is expected during cooler water periods when

389 early viral replication out-paces the delayed onset of the protective innate response. Regardless

390 of the disease pace, herring in the VHS recovery stage often present with classic hemorrhages on

391 internal and external surfaces as a result of hemoglobin leakage from damaged tissues.

392 Infectious virus can be recovered from the tissues of survivors from 2 weeks to 6 months after

393 exposure, depending on the disease trajectory and water temperature.

394 Refractory Stage

Pacific herring that survive infections with VHSV become refractory to the disease for

396 extended periods, presumably for life. Protection against future outbreaks of the disease is most

397 likely conferred by the production of specific antibodies (Hershberger et al. 2011b; Wilson et al.

398 2014) that remain protective at very low circulating titers. Although VHS virus is eventually

399 cleared from the systemic tissues of recovered and refractory individuals, it can persist covertly

400 for extended periods in the immunologically-privileged cells of the central nervous system,

401 including the brain and peripheral nerves (Lovy et al. 2012). Further research is necessary to

402 determine whether the disease can reactivate in these neurotropic carriers, and whether these

403 carriers serve as a source of exogenous virus for infecting other herring. Even though VHS

404 survivors develop strong acquired resistance and become refractory for life, re-exposure of

405 refractory individuals can result in some additional viral replication. Therefore, even refractory

406 individuals likely serve an important role in magnifying and perpetuating VHS virus in wild

407 herring populations. 

designing VHS surveillance strategies and forecasting future potential for epizootics in wild populations. For example, predisposition of herring to VHS epizootics is influenced by

411 exposure, low ambient water temperatures, diet, and elevated infection pressures that are caused 412 by host behavioral patterns, copious viral shedding, and water circulation patterns that facilitate 413 waterborne transmission. However, these host and environmental factors provide little capacity 414 for forecasting VHS epizootics, as one or more of these factors frequently co-occurs in the 415 absence of observable host epizootics. A more quantifiable means of forecasting VHS potential 416 involves the concepts of adaptive immunity and acquired resistance, as the exposure of refractory 417 individuals to high levels of virus, in combination with any or all of the aforementioned 418 environmental co-factors, will not result in a disease epizootic. Therefore, when applied on a 419 population scale, serological assays that are capable of assessing prior host exposures to VHS 420 virus may provide a quantifiable measure of population resistance. The disease potential would 421 be greatly reduced in those populations with serological evidence of prior exposure to VHS 422 virus. Conversely, disease potential would be high in populations lacking evidence of prior 423 exposure, where disease epizootics would likely occur given the proper host and environmental 424 factors. Efforts are currently underway to develop high throughput serological assays that are 425 capable of assessing prior exposure to VHS virus. From a disease management perspective, $a$ 426 priori knowledge of the resistance status of populations would allow resource managers to only 427 open certain herring confinement fisheries during periods of high population resistance; thereby 428 minimizing both disease risk in the confined cohorts and spillback to free-ranging populations.

429 Similarly, the results of humoral surveillances would be much more easily interpreted and 430 incorporated into population models by providing binomial data (susceptible or refractory). 


\section{Discussion}

Since the time of its first documentation from freshwater rainbow trout farms in Germany

433

434

435

436

437

438

439

440

441

442

443

444 inverse relationship between temperature and VHS severity is consistent between numerous

445 strains of VHS virus. Therefore, it is suggested that a more holistic view of the virus could be

446 obtained by considering the entire body of scientific literature surrounding VHS virus, rather

447 than focusing too narrowly on genotype-specific cases. Using this expanded body of literature,

448 we can gain insights into the disease that encompass more than 60 years of observational and

449 empirical research.

The current state of knowledge regarding the ecology of diseases in wild marine fishes is

452 in its infancy, primarily because of the inherent difficulties involved in observing and studying 
453 disease mechanisms that occur in the ocean. As such, the principles described here for VHS

454 represent perhaps our most complete ecological understanding of a disease that impacts

455 populations of wild marine fishes. It is recommended that these principles form the foundation

456 for new mathematical models that can be useful for assigning annual rates of disease-related

457 mortality and for forecasting recruitment into adult spawning populations. The integration of

458 disease information into stock assessment models for wild marine fish populations is generally

459 under-represented or is based on gross estimations that are not based on biological data. In the

460 case of Pacific herring and VHS in Prince William Sound, AK, annual disease mortality is

461 estimated using an index of infection and disease prevalence (Marty et al. 2010). Unfortunately,

462 the ecological disease principles described here provide no indication that VHSV infection

463 prevalence data provide any capacity for forecasting future disease-related mortality. Rather, the

464 disease principles are ideally suited for an alternative approach such as a standard susceptible -

465 infected - recovered (SIR) model, where metrics of population resistance can be quantitatively

466 assessed and employed as a disease forecasting tool. Each disease system is governed by a

467 unique set of ecological principles; therefore, it is recommended that analogous ecological

468 principles be defined for other marine diseases prior to their integration into resource

469 management models.

\section{Acknowledgments}

471 Funding was provided by the Exxon Valdez Oil Spill Trustee Council, Project \# 12120111-K and

472 the U.S. Geological Survey - Fisheries Program, Ecosystems Mission Area. The use of trade,

473 firm, or corporation names in this publication is for the information and convenience of the

474 reader. Such use does not constitute an official endorsement or approval by the U.S. Government

475 of any product or service to the exclusion of others that may be suitable.

\section{$476 \quad$ Literature Cited}


477 Altunas, C., and Ogut, H. 2010. Monthly occurrence and prevalence of viral hemorrhagic septicaemia virus (VHSV) in whiting Merlangius merlangus. Dis. Aquat. Org. 88: 107-113.

479

480

481

482

483

484

485

486

487

488

489

490

491

492

493

494

495

496

497

Arkush, K.D., Mendonca, H.L., McBride, A.M., Yun, S., McDowell, T.S., and Hedrick, R.P. 2006. Effects of temperature on infectivity and commercial freezing on survival of the North American strain of viral hemorrhagic septicemia virus (VHSV). Dis. Aquat. Org 69: 145151.

Beaulaurier, J., Bickford, N., Gregg, J.L., Grady, C.A., Gannam, A., Winton, J.R., and Hershberger, P.K. 2012. Susceptibility of Pacific herring Clupea pallasii to viral hemorrhagic septicemia (VHS) is influenced by diet. J. Aquat. Anim. Hlth. 24: 43-48.

Cury, P., Bakun, A., Crawford, R.J.M., Jarre, A., Quiñones, R.A., Shannon, L.J., and Verheye, H.M. 2000. Small pelagics in upwelling systems: patterns of interaction and structural changes in "wasp waist” ecosystems. ICES J. Mar. Sci 57: 603-618.

Dixon, P.F., Avery, S., Chambers, E., Feist, S., Mandhar, H., Parry, L., Stone, D.M., Strømmen, H.K., Thurlow J.K., Tsin-yee Lui, C., and Way, K. 2003. Four years of monitoring for viral haemorrhagic septicaemia virus in marine waters around the United Kingdom. Dis Aquat. Org. 54: 175-186.

Fauchald, P., Skov, H., Skern-Mauritzen, M., Johns, D., and Tveraa, T. 2011. Wasp-waist interactions in the North Sea ecosystem. PLoS ONE 6(7): e22729.

Follett, J.E., Meyers, T.R., Burton, T.O., and Geesin, J.L. 1997. Comparative susceptibilities of salmonid species in Alaska to infectious hematopoietic necrosis virus (IHNV) and North American viral hemorrhagic septicemia virus (VHSV). J. Aquat. Anim. Hlth. 9: 34-40. 
498 499

500

501

502

503

504

505

506

507

508

509

510

511

512

513

514

515

516

517

518

519

Foreman, M.G.G., Guo, M., Garver, K.A., Stucchi, D., Chandler, P., Wan, D., Morrison, J., and Tuele, D. 2015. Modelling Infectious Hematopoietic Necrosis Virus Dispersion from Marine Salmon Farms in the Discovery Islands, British Columbia, Canada. PLoS ONE 10: 6. :e0130951. doi:10.1371/journal.pone.0130951

Gadd, T., Jakava-Viljanen, M., Tapiovaara, H., Koski, P., and Sihhvonen, L. 2011. Epidemiological aspects of viral hemorrhagic septicemia virus genotype II isolated from Baltic herring, Clupea harengus membras L. J. Fish Dis. 34: 517-529.

Garver, K.A., Hawley, L.M., McClure, C.A., Schroeder, T., Aldous, S., Doig, F., Snow, M., Edes, S., Baynes, C., and Richard, J. 2011. Development and validation of a reverse transcription quantitative PCR (RT-qPCR) for universal detection of viral hemorrhagic septicemia virus. Dis. Aquat. Org. 95: 97-112.

Garver, K.A., Traxler, G.S., Hawley, L.M., Richard, J., Ross, J., and Lovy, J. 2013. Molecular epidemiology of viral haemorrhagic septicaemia virus (VHSV) in British Columbia, Canada, reveals transmission from wild to farmed fish. Dis. Aquat. Org. 104: 93-104.

Goodwin, A.E., and Merry, G.E. 2011. Mortality and carrier status of bluegills exposed to viral hemorrhagic septicemia virus Genotype IVb at different temperatures. J. Aquat. Anim. Hlth. 23: $85-91$.

Hawley, L.M., and Garver, K.A. 2008. Stability of viral hemorrhagic septicemia virus (VHSV) in freshwater and seawater at various temperatures. Dis. Aquat. Org. 82: 171-178.

Hedrick, R.P., Batts, W.N., Yun, S., Traxler, G.S., Kaufman, J., and Winton, J.R. 2003. Host and geographic range extensions of the North American strain of viral hemorrhagic septicemia virus. Dis. Aquat. Org. 55: 211-220. 
520 Hershberger, P.K., Kocan, R.M., Elder, N.E., Meyers, T.R., and Winton, J.R. 1999.

521 Epizootiology of viral hemorrhagic septicemia virus in herring from the closed pound spawn522 on-kelp fishery. Dis. Aquat. Org. 37: 23-31.

523 Hershberger, P.K., Gregg, J., Pacheco, C., Winton, J., Richard, J., and Traxler, G. 2007. Larval

524 Pacific herring, Clupea pallasii (Valenciennes), are highly susceptible to viral hemorrhagic 525 septicemia and survivors are partially protected after their metamorphosis to juveniles. J. $526 \quad$ Fish Dis 30: 445-458.

527 Hershberger, P.K., Elder, N.E., Grady, C.A., Gregg, J.L., Pacheco, C.A., Greene, C., Rice, C., and 528 Meyers, T.R. 2009. Prevalence of viral erythrocytic necrosis in Pacific herring and epizootics 529 in Skagit Bay, Puget Sound, Washington. J. Aquat. Anim. Hlth. 21: 1-7.

530 Hershberger, P., Gregg, J., Grady, C., Collins, R., and Winton, J. 2010a. Kinetics of viral 531 shedding provide insights into the epidemiology of viral hemorrhagic septicemia in Pacific 532 herring. Mar. Ecol. Prog. Ser. 400: 187-193. 
533 Hershberger, P.K., Gregg, J.L., Grady, C.A., Taylor, L., and Winton, J.R.. 2010b. Chronic and 534 persistent viral hemorrhagic septicemia virus infections in Pacific herring. Dis. Aquat. Org. 535 93: 43-49.

536

537

538

539

540

541

542

543

544

545

546

547

548

549

550

551

552

Hershberger, P.K., Gregg, J.L., Grady, C.A., Collins, R.M., and Winton, J.R. 2010c.

Susceptibility of three stocks of Pacific herring to viral hemorrhagic septicemia. J. Aquat. Anim. Hlth. 22: 1-7.

Hershberger, P.K., Gregg, J.L., Grady, C.A., Hart, L., Roon, S.E., and Winton, J.R. 2011 1a. Factors controlling the early stages of viral hemorrhagic septicemia epizootics: low exposure levels, virus amplification, and fish-to-fish transmission. J. Fish Dis. 34: 893-899.

Hershberger, P.K., Gregg, J.L., Grady, C.A., LaPatra, S.E., and Winton, J.R. 2011b. Passive immunization of Pacific herring Clupea pallasii against viral hemorrhagic septicemia. J. Aquat. Anim. Hlth, 23: 140-147.

Hershberger, P.K., Purcell, M.K., Hart, L.M., Gregg, J.L., Thompson, R.L., Garver, K.A., and Winton, J.R. 2013. Influence of temperature on viral hemorrhagic septicemia (Genogroup IVa) in Pacific herring, Clupea pallasii Valenciennes. J. Exp. Mar. Biol. Ecol. 444: 81-86.

Holland, J., Spindler, K., Horodyski, F., Grabau, E., Nichol, S., and VandePol, S. 1982. Rapid Evolution of RVA genomes. Science 215: 1577-1585.

Isshiki, T., Nishizawa, T., Kobayashi, T., Nagano, T., and Miyazaki, T. 2001. An outbreak of VHSV (viral hemorrhagic septicemia virus) infection in farmed Japanese flounder Paralichthys olivaceus in Japan. Dis. Aquat. Org. 47: 87-99. 
553 Kent, M.L., Traxler, G.S., Kieser, D., Richard, J., Dawe, S.C., Shaw, R.W., Prosperi-Porta, G., 554 Ketcheson, J., and Evelyn, T.P.T. 1998. Survey of salmonid pathogens in ocean-caught fishes 555 in British Columbia, Canada. J. Aquat. Anim. Hlth 10: 211-219.

556 Kim, R., and Faisal, M. 2011. Emergence and resurgence of the viral hemorrhagic septicemia 557 virus (Novirhabdovirus, Rhabdoviridae, Mononegavirales). J. Adv. Res. 2: 9-23.

558 Kim, R.K., and Faisal, M. 2012. Shedding of viral hemorrhagic septicemia virus (Genotype $559 \quad \mathrm{IVb}$ ) by experimentally infected muskellunge (Esox masquinongy). J. Microbiol. 50: 278560284.

561 King, J.A., Snow, M., and Raynard, D.A. 2001. Distribution of viral haemorrhagic septicaemia 562 virus in wild fish species of the North Sea, north east Atlantic Ocean, and Irish Sea. Dis. $563 \quad$ Aquat. Org. 47: 81-86.

564 Kocan, R., Bradley, M., Elder, N., Meyers, T., Batts, W., and Winton, J. 1997. North American 565 strain of Viral hemorrhagic septicemia virus is highly pathogenic for laboratory-reared 566 Pacific herring. J. Aquat. Anim. Hlth. 9: 279-290.

567 Kocan, R., Hershberger, P., Mehl, T., Elder, N., Bradley, M., Wildermuth, D., and Stick, K. 568 1999. Pathogenicity of Ichthyophonus hoferi for laboratory-reared Pacific herring (Clupea 569 pallasi) and its early appearance in wild Puget Sound herring. Dis. Aquat. Org. 35: 23-29.

570 Kocan, R.M., Hershberger, P.K., Elder, N.E., and Winton, J.R. 2001a. Epidemiology of viral 571 hemorrhagic septicemia (VHS) among juvenile Pacific herring and Pacific sandlances in 572 Puget Sound, Washington. J. Aquat. Anim. Hlth. 13: 77-85. 
573 Kocan, R.M., Hershberger, P.K., and Elder, N.E. 2001b. Survival of the North American strain 574 of viral hemorrhagic septicemia virus (VHSV) in filtered seawater and seawater containing 575 ovarian fluid, crude oil, and serum-enriched culture medium. Dis. Aquat. Org. 44: 75-78.

576 Lovy, J., Lewis, N.L., Hershberger, P.K., Bennett, W., Meyers, T.R., and Garver, K.A. 2012.

577 Viral tropism and pathology associated with viral hemorrhagic septicemia in larval and 578 juvenile Pacific herring. Vet. Microbiol. 161: 66-76.

579 580 581 582 583 584 585 586 587 588 589 590 591 592 593

Lovy, J., Piesik, P., Hershberger, P.K., and Garver, K.A. 2013. Experimental infection studies demonstrating Atlantic salmon as a host and reservoir of viral hemorrhagic septicemia virus type IVa with insights into pathology and host immunity. Vet. Microbiol. 166: 91-101.

MacFarlane, G.A., and Beamish, R.J. 2001. The re-occurrence of sardines off British Columbia characterizes the dynamics of regimes. Progr. Oceanog. 49: 151-161.

Marty, G.D., Frieberg, E.F., Meyers, T.R., Wilcock, J., Farver, T.B., and Hinton, D.E. 1998. Viral hemorrhagic septicemia virus, Ichthyophonus hoferi, and other causes of morbidity in Pacific herring Clupea pallasi spawning in Prince William Sound, Alaska, USA. Dis. Aquat. Org. 32: 15-40.

Marty. G.D., Quinn II, T.J., Carpenter, G., Meyers, T.R., and Willits, N.H. 2003. Role of disease in abundance of a Pacific herring (Clupea pallasi) population. Can. J. Fish. Aquat. Sci. 60: 1258-1265.

Marty, G.D., Hulson, P.J.F., Miller, S.E., Quinn II, T.J., Moffitt, S.D., and Merizon, R.A. 2010. Failure of population recovery in relation to disease in Pacific herring. Dis. Aquat. Org. 90: 1-14. 
594 Matejusova, I., McKay, P., Bland, F., and Snow, M. 2010. Application of a sensitive, specific 595 and controlled real-time RCR assay to surveillance indicates low prevalence of viral 596 haemorrhagic septicaemia virus (VHSV) in wild herring, Clupea harengus L., in Scottish 597 waters. J. Fish Dis. 33: 841-847.

598 Mortenson, H.F., Heur, O.E., Lorenzen, N., Otte, L., and Olesen, N.J. 1999. Isolation of viral 599 haemorrhagic septicaemia virus (VHSV) from wild marine fish species in the Baltic, $600 \quad$ Kattegat, Skagerrak, and the North Sea. Virus Res. 63: 95-106.

601 Oye, A.K., and Rimstad, E. 2001. Inactivation of infectious salmon anemia virus, viral 602 haemorrhagic septicaemia virus, and infectious pancreatic necrosis virus in water using UVC 603 irradiation. Dis. Aquat. Org. 48: 1-5.

604 Salama, N.K.G., and Rabe, B. 2013. Developing models for investigating the environmental 605 transmission of disease-agents with open-cage salmon aquaculture. Aquacult. Env. Interact. $606 \quad 4: 91-115$.

607 Skall, H.F., Olesen, N.J., and Mellergaard, S. 2005. Viral haemorrgagic septicaemia virus in 608 marine fishes and its implications for fish farming - a review. J. Fish Dis. 28: 502-529.

609 Snow, M., Bain, N., Black, J., Taupin, V., Cunningham, C.O., King, J.A., Skall, H.F., and 610 Raynard, R.S. 2004. Genetic population structure of marine viral haemorrhagic septicaemia 611 virus (VHSV). Dis. Aquat. Org. 61: 11-21.

612 Taylor, F.H.C., and Kieser, R. 1982. Distribution and abundance of herring and other pelagic 613 fish off the west coast of Vancouver Island in September, November, 1980, and March 1981, 614 and the Strait of Georgia in November, 1980. DFO. Can. Manuscript Rept. Fish. Aquat. Sci. $615 \quad$ No. 1682.167 p. 
616 Wilson, A.E., Goldberg, T.L., Marquenski, S.V., Olson, W.J., Goetz, R.F., Hershberger, P.K., and

617 Toohey-Kurth, K.L. 2014. Development and evaluation of a blocking enzyme-linked immunosorbent 618 assay and virus neutralization assay to detect antibodies to viral hemorrhagic septicemia. Clin. Vac. 619 Immun. 21: 435-442.

620 Winton, J.R., Batts, W.N., Deering, R.E., Brunson, R., Hopper, K., Nishizawa, T., and Stehr, C. 621 1991. Characteristics of the first North American isolates of viral hemorrhagic septicemia 622 virus. In Proc. $2^{\text {nd }}$ Int. Symp. Viruses of Lower Vertebrates. Corvallis, Oregon, July 29-31, 623 1991. Oregon State University Press, Corvallis, OR, pp. 43-50.

624 Wolf, K. 1988. Fish viruses and fish viral diseases. Cornell University Press, London, p 217625 249. 

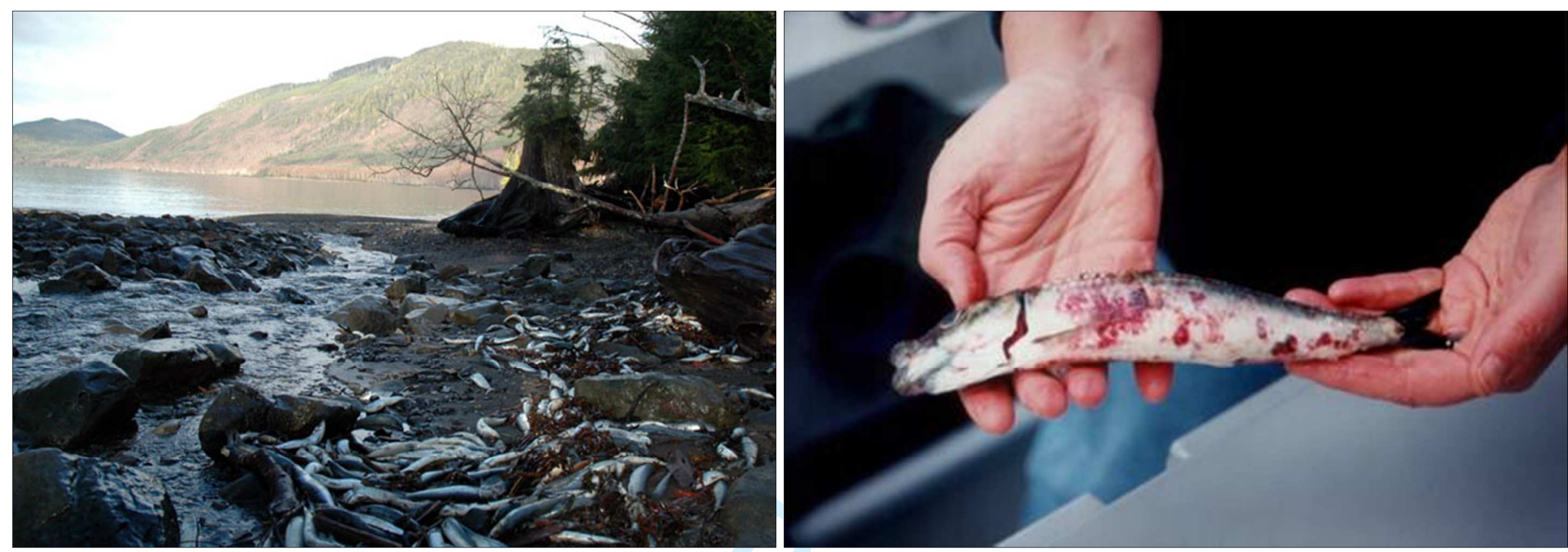

Figure 1. VHS epizootic and associated fish kill involving wild herring in Vancouver Island, B.C, Canada. Visible signs of the disease include hemorrhages along the flank of affected fish. Photo credits: Garth Traxler and Jon Richard, DFO Pacific Biological Station, Canada. 